\section{Cancer incidence, hospital morbidity, and mortality in young adults in Brazil}

\author{
Incidência, morbidade hospitalar e mortalidade \\ por câncer em adultos jovens no Brasil \\ Incidencia, morbilidad hospitalaria y mortalidad \\ por cáncer en adultos jóvenes en Brasil
}

\begin{abstract}
1 Escola Nacional de Saúde Pública Sergio Arouca, Fundação Oswaldo Cruz, Rio de Janeiro, Brasil.

Correspondence S. S. Santos

Escola Nacional de Saúde Pública Sergio Arouca, Fundação Oswaldo Cruz. Rua Leopoldo Bulhões 1480 , Rio de Janeiro, $R J$ 21041-210, Brasil. sabrina_ssantos@hotmail.com
\end{abstract}

\begin{abstract}
There are still relatively few studies in the world on cancer incidence and mortality in young adults. The current study aimed to explore cancer distribution in young adults in Brazil. A descriptive study was conducted on cancer incidence (selected State capitals), hospital morbidity, and mortality (Brazil and selected capitals) in the 2024-year age strata in 2000-2002, and trends in cancer mortality rates in Brazil in 1980-2008 in the same population. Testicular cancer was the principal anatomical site in young adult males; in young adult women, the main sites were thyroid, uterine cervix, and Hodgkin disease. Brain cancer was the principal cause of death from cancer in both sexes, and time trends in mortality showed an increase in mortality from brain cancer in men and from lymphocytic leukemia in both sexes. As a whole, the results show an epidemiological pattern of cancer in young adults with regional distribution characteristics.
\end{abstract}

Neoplams; Young Adult; Morbidity; Mortality
Sabrina da Silva Santos 1 Leticia Rodrigues Melo 1 Rosalina Jorge Koifman 1 Sergio Koifman 1

\section{Resumo}

No mundo, ainda são relativamente poucos os estudos sobre a incidência e mortalidade por câncer em adultos jovens. O objetivo foi explorar a distribuição de câncer em adultos jovens no Brasil. Foi realizado um estudo descritivo da incidência (capitais selecionadas), da morbidade hospitalar e da mortalidade (Brasil e capitais selecionadas) por câncer aos 20-24 anos, no período de 2000-2002, e da evolução das taxas de mortalidade por câncer no Brasil no período de 1980-2008, na mesma população. O câncer de testículo foi a principal localização anatômica em homens; $e$ as neoplasias da glândula tireoide, do colo de útero e a doença de Hodgkin nas mulheres. O câncer de encéfalo foi a principal causa de óbito por câncer em ambos os sexos, e a tendência temporal da mortalidade mostra um aumento da mortalidade por câncer de encéfalo em homens e pela leucemia linfoide em ambos os sexos. Em conjunto, os resultados apresentados retratam um padrão epidemiológico de câncer em adultos jovens no Brasil com características regionais de distribuição.

Neoplasias; Adulto Jovem; Morbidade; Mortalidade 


\section{Introduction}

After years of studies on the distribution of neoplasms in children and adults, increasing international research has focused on cancer in adolescents and young adults 1 . However, there are still relatively few studies with a detailed characterization of the distribution of cancer incidence and mortality rates in young people or which explore the biological characteristics of these tumors 2 .

The current interest in cancer in young adults is due partly to the limited progress in oncologic treatment in this age group as compared to children or older adults. Some cancers frequently show worse survival in adolescents (15-19 years) and young adults (20-24 years) as compared to other age strata. These include breast cancer, colorectal cancer, soft tissue sarcoma, non-Hodgkin lymphoma, and leukemia ${ }^{3}$. One possible explanation for this heterogeneity is that most therapies administered to adolescents and young adults were derived from therapies originally designed for other age brackets, besides the relative lack of clinical trials and studies with tumor samples from these patients. This scenario may have led to a lack of opportunities for exploring and discovering potential biological differences between tumors in adolescents and young adults and those in other age groups 4 . In addition, cancer in young people is associated with a particularly significant emotional burden, and it is often difficult for young people to accept treatments that jeopardize their independence or that may have lasting effects on their body image and fertility 5,6.

Most neoplasms currently diagnosed in young adults lack known genetic or environmental risk factors. Most of these neoplasms are known to consist of sporadic tumors, that is, they affect individuals without a family history of cancer clusters. This age strata rarely involves inherited cancer syndromes, i.e., those in which individuals have a high lifetime risk of developing a neoplasm 7 .

The objective of this study was to conduct an exploratory analysis of the distribution of cancer incidence, hospital morbidity, and mortality in young adults in Brazil.

\section{Material and methods}

\section{Study design}

A descriptive study was conducted on the distribution of cancer incidence rates (in selected cities), hospital morbidity, and mortality (in Brazil as a whole and in selected cities) in young adults (20-24 years) in Brazil according to gender from 2000 to 2002. A descriptive study was also per- formed on cancer mortality rates by gender in young Brazilians in the same age bracket from 1980 to 2008.

\section{Analysis of incidence}

Incidence data on cancer were obtained from population-based cancer registries (Instituto Nacional de Câncer. http://www2.inca.gov.br/wps/ $\mathrm{wcm} /$ connect/estatisticas/site/home/ $\mathrm{rcbp} /$, accessed on 01/Jan/2011) for Brazilian State capitals that maintained such registries and that met the following data quality criteria: microscopic verification (histological, cytological, or hematological examination) in more than $75 \%$ of cases; fewer than $20 \%$ of cases only reported by death certificate; fewer than $5 \%$ of malignant neoplasms without specification of site (C80); and fewer than $15 \%$ of cases with the patient's age missing ${ }^{8}$. The study thus included and analyzed cancer incidence for the populations of São Paulo, Porto Alegre (Rio Grande do Sul State), João Pessoa (Paraíba), Goiânia (Goiás), Fortaleza (Ceará), Cuiabá (Mato Grosso), Belo Horizonte (Minas Gerais), and Aracaju (Sergipe).

Cancer incidence rates were calculated for 2000-2002. This period was chosen because it was the only one in which all the data were available from the population-based cancer registries. Cancer incidence rates were calculated for all sites except non-melanoma skin cancer and for the principal sites in the State capitals, for both males and females.

\section{Analysis of hospital morbidity}

To estimate the impact of cancer as the cause of illness, the study calculated the proportions of hospital admissions for cancer in patients 20 to 24 years of age according to gender for the period 2000-2002, in the same incidence rates were analyzed and for Brazil as a whole. Hospital morbidity data were obtained from the database of the Health Informatics Department (DATASUS. http://www2.datasus.gov.br/DATASUS/index. php?area $=02$, accessed on $01 / \operatorname{Jan} / 2011$ ). The proportions of hospital admissions due to cancer were calculated using as the denominator all admissions in the National Health System (excluding childbirth and postpartum) in the same age bracket and according to gender.

\section{Analysis of mortality}

Mortality data (1980-2008) were obtained from the database of the DATASUS (http://www2. datasus.gov.br/DATASUS/index.php?area $=02$, accessed on $01 / \mathrm{Jan} / 2011$ ) in the same cities 
where in incidence rates were analyzed and for Brazil as a whole. Mortality rates were calculated according to gender for 2000-2002. This period was chosen because it was the same used to analyze incidence, thus allowing comparison of the two indicators (mortality and incidence). Mortality rates were presented for all tumor sites, in addition to the mortality rates for the sites with the highest rates in Brazil as a whole and in the selected cities. Cancer was also ranked in comparison to other causes of death (chapters in the International Classification of Diseases, 10th Revision - ICD-10).

Distributions of mortality rates from cancer for all sites and for the sites with the highest mortality rates in Brazil, by gender, were explored for the period 1980-2008. Poisson (log) regression was used for this purpose, with mortality rate (per 100,000) as the dependent variable, centralized calendar year as the independent variable, and assuming continuous variance throughout the target period. The study used Joinpoint 3.5.2 (http://www.cancer.org) to calculate the average annual percent change (AAPC) in the respective distributions.

\section{Population data}

The populations of men and women living in Brazil and in each selected city were obtained from DATASUS based on the population censuses from 1980, 1991, and 2000, the 1996 count, and inter-census projections (1981-2009). These populations were used in calculating the incidence and mortality rates for each gender.

\section{Results}

\section{Incidence}

Table 1 shows the absolute distribution and incidence rates for cancer for 2000-2002 in men 20-24 years of age in the selected Brazilian State capitals. The highest incidence rate for all sites except non-melanoma skin cancer was

Table 1

Cancer incidence in main anatomical sites in selected cities, males, 20-24 years, Brazil, 2000-2002.

\begin{tabular}{|c|c|c|c|c|c|c|c|c|c|c|c|c|c|c|c|c|}
\hline \multirow{2}{*}{$\begin{array}{l}\text { Type of cancer } \\
\text { (ICD-10) }\end{array}$} & \multicolumn{2}{|c|}{ São Paulo } & \multicolumn{2}{|c|}{ Porto Alegre } & \multicolumn{2}{|c|}{ João Pessoa } & \multicolumn{2}{|c|}{ Goiânia } & \multicolumn{2}{|c|}{ Fortaleza } & \multicolumn{2}{|c|}{ Cuiabá } & \multicolumn{2}{|c|}{ Belo Horizonte } & \multicolumn{2}{|c|}{ Aracaju } \\
\hline & $\mathbf{n}$ & Rate & $\mathrm{n}$ & Rate & $\mathbf{n}$ & Rate & $\mathbf{n}$ & Rate & n & Rate & $\mathbf{n}$ & Rate & $\mathrm{n}$ & Rate & $\mathrm{n}$ & Rate \\
\hline Total * & 481 & 32.1 & 77 & 42.0 & 12 & 13.7 & 37 & 20.7 & 62 & 20.3 & 24 & 31.2 & 69 & 20.3 & 15 & 21.0 \\
\hline Testis (C62) & 65 & $4.3^{* \star}$ & 20 & 10.9 ** & 0 & 0.0 & 5 & 2.8 ** & 7 & 2.3 & 2 & 2.6 & 14 & $4.1^{\star \star}$ & 2 & 2.8 \\
\hline $\begin{array}{l}\text { Non-Hodgkin lymphoma } \\
\text { (C82, C83, C85) }\end{array}$ & 42 & 2.8 & 4 & 2.2 & 4 & 4.6 ** & 2 & 1.1 & 8 & 2.6 & 0 & 0.0 & 11 & 3.2 & 1 & 1.4 \\
\hline Hodgkin disease (C81) & 41 & 2.7 & 6 & 3.3 & 0 & 0.0 & 4 & 2.2 & 6 & 2.0 & 1 & 1.3 & 8 & 2.4 & 1 & 1.4 \\
\hline $\begin{array}{l}\text { Bones and articular } \\
\text { cartilage (C40, C41) }\end{array}$ & 38 & 2.5 & 6 & 3.3 & 1 & 1.1 & 5 & 2.8 *夫 & 3 & 1.0 & 5 & $6.5 * \star$ & 6 & 1.8 & 4 & 5.6 *夫 \\
\hline Brain (C71) & 31 & 2.1 & 6 & 3.3 & 0 & 0.0 & 4 & 2.2 & 11 & $3.6 * \star$ & 1 & 1.3 & 1 & 0.3 & 2 & 2.8 \\
\hline Myeloid leukemia (C92) & 27 & 1.8 & 1 & 0.6 & 1 & 1.1 & 3 & 1.7 & 3 & 1.0 & 2 & 2.6 & 2 & 0.6 & 0 & 0.0 \\
\hline $\begin{array}{l}\text { Lymphocytic leukemia } \\
\text { (C91) }\end{array}$ & 22 & 1.5 & 4 & 2.2 & 0 & 0.0 & 0 & 0.0 & 3 & 1.0 & 2 & 2.6 & 4 & 1.2 & 1 & 1.4 \\
\hline $\begin{array}{l}\text { Connective tissue and } \\
\text { other soft tissues (C49) }\end{array}$ & 19 & 1.3 & 4 & 2.2 & 0 & 0.0 & 2 & 1.1 & 3 & 1.0 & 1 & 1.3 & 6 & 1.8 & 0 & 0.0 \\
\hline Thyroid gland (C73) & 17 & 1.1 & 5 & 2.7 & 2 & 2.3 & 0 & 0.0 & 2 & 0.6 & 1 & 1.3 & 0 & 0.0 & 2 & 2.8 \\
\hline Colon (C18) & 11 & 0.7 & 0 & 0.0 & 0 & 0.0 & 2 & 1.1 & 3 & 1.0 & 0 & 0.0 & 0 & 0.0 & 1 & 1.4 \\
\hline Melanoma (C43) & 11 & 0.7 & 5 & 2.7 & 1 & 1.1 & 1 & 0.6 & 1 & 0.3 & 0 & 0.0 & 1 & 0.3 & 0 & 0.0 \\
\hline Stomach (C16) & 11 & 0.7 & 1 & 0.6 & 0 & 0.0 & 1 & 0.6 & 1 & 0.3 & 1 & 1.3 & 2 & 0.6 & 0 & 0.0 \\
\hline $\begin{array}{l}\text { Leukemia, cell type } \\
\text { unspecified (C95) }\end{array}$ & 11 & 0.7 & 0 & 0.0 & 0 & 0.0 & 1 & 0.6 & 1 & 0.3 & 1 & 1.3 & 1 & 0.3 & 0 & 0.0 \\
\hline Bronchi and lungs (C34) & 6 & 0.4 & 1 & 0.6 & 0 & 0.0 & 2 & 1.1 & 0 & 0.0 & 0 & 0.0 & 0 & 0.0 & 1 & 1.4 \\
\hline
\end{tabular}

ICD-10: International Classification of Diseases, 10th Revision.

* Excludes non-melanoma skin cancer;

** Highest incidence rate in the city during this period. 
observed in Porto Alegre (42.0 cases/100,000), followed by São Paulo $(32.1 / 100,000)$ and Cuiabá (31.2/100,000). Aracaju (21.0/100,000), Goiânia (20.7/100,000), Belo Horizonte $(20.3 / 100,000)$, and Fortaleza $(20.3 / 100,000)$ showed intermediate rates, while João Pessoa presented the lowest rate $(13.7 / 100,000)$.

The main cancer site in young men during this period was testicular cancer, the tumor site with the highest incidence rate in the cities of Porto Alegre (10.9 cases/100,000), São Paulo (4.3/100,000), Belo Horizonte $(4.1 / 100,000)$, and Goiânia (2.8/100,000). In Cuiabá $(2.6 / 100,000)$ and Aracaju (2.8/100,000), testicular cancer was the second leading site for cancer incidence among 20-24-year-old males.

For non-Hodgkin lymphoma, the highest incidence rate in this period was seen in João Pessoa $(4.6$ cases/100,000), where it was the leading cause of cancer in men, followed by Belo Horizonte $(3.2 / 100,000)$, São Paulo $(2.8 / 100,000)$, Fortaleza $(2.6 / 100,000)$, and Porto Alegre $(2.2 / 100,000)$.

In men, tumors of bones and articular cartilage comprised the main site in Cuiabá (6.5 cases/100,000) and Aracaju (5.6/100,000) and one of the principal sites in Goiânia $(2.8 / 100,000)$. Meanwhile, brain cancer was the tumor site with the highest incidence rate in Fortaleza $(3.6 / 100,000)$ and presenting similar rate in Porto Alegre $(3.3 / 100,000)$.

For women 20 to 24 years of age, São Paulo showed the highest cancer incidence rate (for all sites except non-melanoma skin cancer) in the selected cities $(36.1 / 100,000)$. In the other cities, the rates were as follows in decreasing order: 35.2/100,000 in Cuiabá, 32.8/100,000 in Aracaju, 30.9/100,000 in Porto Alegre, 25.2/100,000 in Goiânia, 23.9/100,000 in Fortaleza, and 22.6/100,000 in Belo Horizonte. João Pessoa showed the lowest incidence rate in females during the target period $(15.2 / 100,000)$ (Table 2).

Cancer of the thyroid was the main site in women de 20 to 24 years of age in five of the eight selected cities: Aracaju (6.1/100,000), São Paulo (6.0/100,000), João Pessoa $(4.1 / 100,000)$, Cuiabá $(3.6 / 100,000)$, and Fortaleza $(3.1 / 100,000)$.

Forcanceroftheuterinecervix,Aracajushowed the highest incidence rate $(6.1$ cases $/ 100,000)$; together with thyroid cancer, it was the site with the highest incidence rate in women in this city. The next highest incidences rates for cervical cancer were observed in São Paulo $(4.8 / 100,000)$, Porto Alegre $(2.6 / 100,000)$, Cuiabá $(2.4 / 100,000)$, Goiânia $(2.1 / 100,000)$, João Pessoa $(2.0 / 100,000)$, and Fortaleza $(1.7 / 100,000)$.

Hodgkin disease was the most common site in young women in Porto Alegre (6.3 cases/100,000), Belo Horizonte $(3.8 / 100,000)$, and Fortaleza
$(3.1 / 100,000)$, but also with high rates in the other cities, except Goiânia (1.5/100,000).

For brain cancer, Aracaju showed the highest incidence rate $(4.9 / 100,000)$, followed by Porto Alegre $(3.1 / 100,000)$. The other cities showed moderate or low rates.

Non-Hodgkin lymphoma was the most common site in young women in Goiânia, 3.1/100,000, the same rate as observed in Porto Alegre and similar to that in Belo Horizonte $(2.8 / 100,000)$. Breast cancer showed the highest incidence rate in Cuiabá $(3.6 / 100,000)$, where it was the leading tumor site in young women, followed by Goiânia $(2.6 / 100,000)$ and Aracaju $(2.4 / 100,000)$.

\section{Hospital morbidity}

Analysis of hospital admissions of young people (20-24 years) in the Brazilian National Health System in 2000-2002 showed that cancer (ICD10 chapter II, excluding benign tumors and nonmelanoma skin cancer) was the $12^{\text {th }}$ cause of hospitalization in men and the $8^{\text {th }}$ cause in women.

In men, cancer accounted for $2 \%$ of all admissions, as compared to $24 \%$ for injuries, poisoning, and other consequences of external causes, which were the leading cause of hospitalization. The proportions of other causes of hospitalization in men were $13 \%$ for diseases of the digestive system, $12 \%$ for diseases of the respiratory system, $10 \%$ for mental and behavioral disorders, $9 \%$ for infectious and parasitic diseases, $6 \%$ for diseases of the genitourinary system, $5 \%$ for diseases of the musculoskeletal system and connective tissue, $3 \%$ for diseases of the circulatory system, $3 \%$ for diseases of the skin, $3 \%$ for diseases of the subcutaneous system, and $2 \%$ for diseases of the nervous system.

In women, excluding childbirth and postpartum, hospital admissions due to cancer accounted for $3 \%$ of all admissions, while the leading cause of admission was diseases of the genitourinary system ( $24 \%$ of all admissions). The proportions of other causes of hospitalization were $15 \%$ for diseases of the digestive system, $13 \%$ for diseases of the respiratory system, $10 \%$ for infectious and parasitic diseases, $6 \%$ for diseases of the circulatory system, $6 \%$ for injuries, poisoning, and other consequences of external causes, and $4 \%$ for mental and behavior disorders.

Cancer was the $8^{\text {th }}$ cause of hospitalization in men 20-24 years of age in Porto Alegre (3\% of all admissions), the $10^{\text {th }}$ cause in Cuiabá (3\%), $11^{\text {th }}$ in João Pessoa (2\%), Aracaju (2\%), Fortaleza (3\%), and Goiânia (2\%), 12th in São Paulo (2\%), and $13^{\text {th }}$ in Belo Horizonte (2\%). In women of the same age bracket, cancer was the 7 th cause of hospitalization in Cuiabá (4\%), 8th in Porto Alegre 
Cancer incidence in main anatomical sites in selected cities, females, 20-24 years, Brazil, 2000-2002.

\begin{tabular}{|c|c|c|c|c|c|c|c|c|c|c|c|c|c|c|c|c|}
\hline \multirow{2}{*}{$\begin{array}{l}\text { Type of cancer } \\
\text { (ICD-10) }\end{array}$} & \multicolumn{2}{|c|}{ São Paulo } & \multicolumn{2}{|c|}{ Porto Alegre } & \multicolumn{2}{|c|}{ João Pessoa } & \multicolumn{2}{|c|}{ Goiânia } & \multicolumn{2}{|c|}{ Fortaleza } & \multicolumn{2}{|c|}{ Cuiabá } & \multicolumn{2}{|c|}{ Belo Horizonte } & \multicolumn{2}{|c|}{ Aracaju } \\
\hline & $\mathrm{n}$ & Rate & $\mathbf{n}$ & Rate & $\mathrm{n}$ & Rate & $\mathbf{n}$ & Rate & $\mathbf{n}$ & Rate & $\mathrm{n}$ & Rate & $\mathbf{n}$ & Rate & $\mathrm{n}$ & Rate \\
\hline Total * & 575 & 36.1 & 59 & 30.9 & 15 & 15.2 & 49 & 25.2 & 84 & 23.9 & 29 & 35.2 & 82 & 22.6 & 27 & 32.8 \\
\hline Thyroid gland (C73) & 95 & 6.0 ** & 4 & 2.1 & 4 & 4.1 *夫 & 0 & 0.0 & 11 & $3.1^{\star \star}$ & 3 & 3.6 ** & 6 & 1.7 & 5 & $6.1^{\star \star}$ \\
\hline Uterine cervix (C53) & 77 & 4.8 & 5 & 2.6 & 2 & 2.0 & 4 & 2.1 & 6 & 1.7 & 2 & 2.4 & 0 & 0 & 5 & 6.1 ** \\
\hline $\begin{array}{l}\text { Hodgkin disease } \\
\text { (C81) }\end{array}$ & 47 & 3.0 & 12 & $6.3^{* \star}$ & 3 & 3.0 & 3 & 1.5 & 11 & $3.1^{* *}$ & 2 & 2.4 & 14 & 3.9 ** & 2 & 2.4 \\
\hline Ovary (C56) & 35 & 2.2 & 1 & 0.5 & 1 & 1.0 & 0 & 0.0 & 7 & 2.0 & 3 & $3.6^{*}$ & 3 & 0.8 & 2 & 2.4 \\
\hline $\begin{array}{l}\text { Myeloid leukemia } \\
\text { (C92) }\end{array}$ & 31 & 1.9 & 1 & 0.5 & 1 & 1.0 & 4 & 2.1 & 3 & 0.9 & 1 & 1.2 & 5 & 1.4 & 0 & 0.0 \\
\hline Brain (C71) & 24 & 1.5 & 6 & 3.1 & 2 & 2.0 & 4 & 2.0 & 8 & 2.3 & 1 & 1.2 & 5 & 1.4 & 4 & 4.9 \\
\hline $\begin{array}{l}\text { Non-Hodgkin } \\
\text { lymphoma (C82, } \\
\text { C83, C85) }\end{array}$ & 24 & 1.5 & 6 & 3.1 & 0 & 0.0 & 6 & 3.1 ** & 7 & 2.0 & 0 & 0.0 & 10 & 2.8 & 1 & 1.2 \\
\hline $\begin{array}{l}\text { Bones and articular } \\
\text { cartilage }(\mathrm{C} 40, \mathrm{C} 41)\end{array}$ & 21 & 1.3 & 0 & 0.0 & 0 & 0.0 & 4 & 2.1 & 2 & 0.6 & 2 & 2.4 & 10 & 2.6 & 2 & 2.4 \\
\hline $\begin{array}{l}\text { Connective tissue } \\
\text { and other soft tissues } \\
\text { (C49) }\end{array}$ & 19 & 1.2 & 3 & 1.6 & 0 & 0.0 & 5 & 2.6 & 2 & 0.6 & 1 & 1.2 & 3 & 0.8 & 1 & 1.2 \\
\hline $\begin{array}{l}\text { Lymphocytic } \\
\text { leukemia (C91) }\end{array}$ & 17 & 1.1 & 0 & 0.0 & 0 & 0.0 & 3 & 1.5 & 2 & 0.6 & 1 & 1.2 & 1 & 0.3 & 1 & 1.2 \\
\hline Breast (C50) & 15 & 0.9 & 3 & 1.6 & 1 & 1.0 & 5 & 2.6 & 6 & 1.7 & 3 & 3.6 ** & 5 & 1.4 & 2 & 2.4 \\
\hline Colon (C18) & 13 & 0.8 & 2 & 1.1 & 0 & 0.0 & 0 & 0.0 & 2 & 0.6 & 1 & 1.2 & 2 & 0.6 & 0 & 0.0 \\
\hline Melanoma (C43) & 13 & 0.8 & 11 & 5.8 & 0 & 0.0 & 2 & 1.0 & 0 & 0.0 & 2 & 2.4 & 3 & 0.8 & 0 & 0.0 \\
\hline Stomach (C16) & 12 & 0.8 & 0 & 0.0 & 0 & 0.0 & 2 & 1.0 & 0 & 0.0 & 0 & 0.0 & 3 & 0.8 & 0 & 0.0 \\
\hline $\begin{array}{l}\text { Bronchi and lungs } \\
\text { (C34) }\end{array}$ & 3 & 0.2 & 0 & 0.0 & 0 & 0.0 & 0 & 0.0 & 2 & 0.6 & 1 & 1.2 & 0 & 0.0 & 0 & 0.0 \\
\hline Uterus (C54. C55) & 2 & 0.1 & 0 & 0.0 & 0 & 0.0 & 0 & 0.0 & 2 & 0.6 & 2 & 2.4 & 0 & 0.0 & 0 & 0.0 \\
\hline
\end{tabular}

ICD-10: International Classification of Diseases, 10th Revision.

* Excludes non-melanoma skin cancer;

** Highest incidence rate in the city in this period.

(4\%), 10th in Aracaju (3\%), and 11th in Goiânia (2\%), Fortaleza (3\%), Belo Horizonte (3\%), and São Paulo (4\%), excluding hospital admissions for childbirth and postpartum.

\section{Mortality}

Among the ICD-10 chapters, cancer (chapter II, excluding benign tumors) was the $4^{\text {th }}$ cause of death in men 20 to 24 years of age in Brazil in 2000-2002, with 7.2 deaths per 100,000 men, next only to external causes $(213.5 / 100,000)$, abnormal symptoms, signs, and clinical and laboratory findings not otherwise specified $(13.3 / 100,000)$, and infectious and parasitic diseases $(9.0 / 100,000)$. In women 20 -24 years of age, during the same period, cancer was the $5^{\text {th }}$ cause of death (5.3/100,000 women), next to external causes (20.9/100,000), abnormal symptoms, signs, and clinical and laboratory findings not otherwise specified $(6.2 / 100,000)$, infectious and parasitic diseases $(5.9 / 100,000)$ and diseases of the circulatory system $(5.4 / 100,000)$.

In relation to the selected cities, cancer was the $2^{\text {nd }}$ cause of death among men 20-24 years of age in São Paulo (9.5/100,000), Goiânia (9.0/100,000), and Belo Horizonte (7.4/100,000, together with infectious and parasitic diseases, diseases of the circulatory system, and diseases of respiratory system). Cancer was the $3^{\text {rd }}$ cause of death in Porto Alegre $(12.0 / 100,000)$ and 5 th in Fortaleza (7.5/100,000), João Pessoa (6.8/100,000, together with diseases of the circulatory system), Cuiabá (5.2/100,000, together with diseases of the nervous system and of the circulatory system), and Aracaju (4.2/100,000, together with 
diseases of the blood and hematopoietic organs and certain immune disorders and diseases of the nervous system, respiratory system, and digestive system).

In women 20-24 years of age, cancer was the 2nd cause of death in São Paulo (6.0/100,000), Goiânia (6.7/100,000, together with diseases of the circulatorysystem), and Aracaju (9.7/100,000), the 3 rd cause of death in Porto Alegre $(8.9 / 100,000)$, Fortaleza (7.1/100,000), Cuiabá $(9.7 / 100,000)$, and Belo Horizonte $(4.1 / 100,000)$, and the $4^{\text {th }}$ cause in João Pessoa (3.0/100,000, together with diseases of the respiratory system and digestive system).

Table 3 shows the mortality rates from cancer in 2000-2002 in men 20-24 years of age in Brazil and in the selected State capitals. Brain cancer showed the highest mortality rate from cancer (0.8 deaths/100,000), followed by neoplasms of the bones and articular cartilage $(0.8 / 100,000)$, lymphocytic leukemia $(0.7 / 100,000)$, myeloid leukemia $(0.7 / 100,000)$, non-Hodgkin lymphoma $(0.6 / 100,000)$, and testicular cancer $(0.4 / 100,000)$.
In relation to brain cancer, Porto Alegre showed the highest mortality rate $(2.2 / 100,000)$, followed by Fortaleza $(2.0 / 100,000)$ and Aracaju $(1.4 / 100,000)$. Porto Alegre also showed the highest mortality rate from tumors of the bones and articular cartilage $(2.2 / 100,000)$, followed by Goiânia $(1.7 / 100,000)$ and Belo Horizonte $(1.2 / 100,000)$.

Lymphocytic leukemia showed the highest mortality rate in Belo Horizonte $(1.2 / 100,000)$ and similar rates in São Paulo and João Pessoa $(1.1 / 100,000)$. As for myeloid leukemia, João Pessoa showed the highest rate $(3.4 / 100,000)$, more than double the rate in some other cities (São Paulo 1.5/100,000; Cuiabá 1.3/100,000). Goiânia showed the highest mortality rate from nonHodgkin lymphoma $(1.1 / 100,000)$, while Aracaju showed the highest mortality rate from testicular cancer $(1.4 / 100,000)$.

Table 4 shows the absolute distribution of deaths and mortality rates from cancer in women 20-24 years of age in Brazil and in the selected State capitals in 2000-2002. As with men, brain cancer showed the highest mortality rate from

Table 3

Cancer mortality in main anatomical sites in selected cities, males, 20-24 years. Brazil, 2000-2002.

\begin{tabular}{|c|c|c|c|c|c|c|c|c|c|c|c|c|c|c|c|c|c|c|}
\hline \multirow{2}{*}{$\begin{array}{l}\text { Type of cancer } \\
\text { (ICD-10) }\end{array}$} & \multicolumn{2}{|c|}{ Brazil } & \multicolumn{2}{|c|}{ São Paulo } & \multicolumn{2}{|c|}{ Porto Alegre } & \multicolumn{2}{|c|}{ João Pessoa } & \multicolumn{2}{|c|}{ Goiânia } & \multicolumn{2}{|c|}{ Fortaleza } & \multicolumn{2}{|c|}{ Cuiabá } & \multicolumn{2}{|c|}{ Belo Horizonte } & \multicolumn{2}{|c|}{ Aracaju } \\
\hline & $\mathrm{n}$ & Rate & $\mathbf{n}$ & Rate & $\mathrm{n}$ & Rate & $\mathrm{n}$ & Rate & $\mathrm{n}$ & Rate & $\mathbf{n}$ & Rate & $\mathrm{n}$ & Rate & $\mathrm{n}$ & Rate & $\mathrm{n}$ & Rate \\
\hline Total & 1,766 & 7.2 & 142 & 9.5 & 22 & 12.0 & 6 & 6.8 & 16 & 9.0 & 23 & 7.5 & 4 & 5.2 & 25 & 7.4 & 3 & 4.2 \\
\hline Brain (C71) & 205 & 0.8 * & 12 & 0.8 & 4 & 2.2 * & 0 & 0.0 & 2 & 1.1 & 6 & 2.0 * & 0 & 0.0 & 0 & 0.0 & 1 & 1.4 * \\
\hline $\begin{array}{l}\text { Bones and articular cartilage } \\
(\mathrm{C} 40, \mathrm{C} 41)\end{array}$ & 184 & 0.8 & 16 & 1.1 & 4 & 2.2 * & 1 & 1.1 & 3 & 1.7 * & 0 & 0.0 & 0 & 0.0 & 4 & 1.2 & 0 & 0.0 \\
\hline Lymphocytic leukemia (C91) & 173 & 0.7 & 16 & 1.1 & 1 & 0.5 & 1 & 1.1 & 1 & 0.6 & 2 & 0.7 & 0 & 0.0 & 4 & 1.2 & 0 & 0.0 \\
\hline Myeloid leukemia (C92) & 164 & 0.7 & 22 & 1.5 * & 0 & 0.0 & 3 & 3.4 * & 2 & 1.1 & 1 & 0.3 & 1 & 1.3 * & 0 & 0.0 & 0 & 0.0 \\
\hline $\begin{array}{l}\text { Non-Hodgkin lymphoma } \\
\text { (C82, C83, C85) }\end{array}$ & 155 & 0.6 & 9 & 0.6 & 1 & 0.5 & 0 & 0.0 & 2 & 1.1 & 2 & 0.7 & 0 & 0.0 & 3 & 0.9 & 0 & 0.0 \\
\hline Testis (C62) & 106 & 0.4 & 16 & 1.1 & 2 & 1.1 & 0 & 0.0 & 2 & 1.1 & 2 & 0.7 & 0 & 0.0 & 2 & 0.6 & 1 & 1.4 * \\
\hline $\begin{array}{l}\text { Leukemia, cell type } \\
\text { unspecified (C95) }\end{array}$ & 69 & 0.3 & 2 & 0.1 & 0 & 0.0 & 0 & 0.0 & 0 & 0.0 & 1 & 0.3 & 1 & 1.3 * & 1 & 0.3 & 0 & 0.0 \\
\hline Hodgkin disease (C81) & 66 & 0.3 & 9 & 0.6 & 0 & 0.0 & 0 & 0.0 & 1 & 0.6 & 1 & 0.3 & 0 & 0.0 & 1 & 0.3 & 0 & 0.0 \\
\hline $\begin{array}{l}\text { Connective tissue and other } \\
\text { soft tissues (C49) }\end{array}$ & 60 & 0.2 & 5 & 0.3 & 4 & 2.2 * & 0 & 0.0 & 0 & 0.0 & 0 & 0.0 & 0 & 0.0 & 2 & 0.6 & 0 & 0.0 \\
\hline Bronchi and lungs (C34) & 52 & 0.2 & 1 & 0.1 & 0 & 0.0 & 0 & 0.0 & 0 & 0.0 & 0 & 0.0 & 1 & 1.3 * & 0 & 0.0 & 0 & 0.0 \\
\hline Liver (C22) & 38 & 0.2 & 4 & 0.3 & 0 & 0.0 & 0 & 0.0 & 0 & 0.0 & 0 & 0.0 & 1 & 1.3 * & 2 & 0.6 & 0 & 0.0 \\
\hline Colon (C18) & 35 & 0.1 & 4 & 0.3 & 0 & 0.0 & 0 & 0.0 & 1 & 0.6 & 1 & 0.3 & 0 & 0.0 & 0 & 0.0 & 0 & 0.0 \\
\hline Stomach (C16) & 34 & 0.1 & 3 & 0.2 & 0 & 0.0 & 0 & 0.0 & 0 & 0.0 & 1 & 0.3 & 0 & 0.0 & 1 & 0.3 & 0 & 0.0 \\
\hline $\begin{array}{l}\text { Spinal column, cranial } \\
\text { nerves, and others (C72) }\end{array}$ & 28 & 0.1 & 2 & 0.1 & 2 & 1.1 & 0 & 0.0 & 0 & 0.0 & 0 & 0.0 & 0 & 0.0 & 1 & 0.3 & 0 & 0.0 \\
\hline
\end{tabular}

ICD-10: International Classification of Diseases, 10th Revision.

* Highest mortality rate in Brazil or in the city during this period. 
Cancer mortality in main anatomical sites in selected cities, females, 20-24 years. Brazil, 2000-2002.

\begin{tabular}{|c|c|c|c|c|c|c|c|c|c|c|c|c|c|c|c|c|c|c|}
\hline \multirow{2}{*}{$\begin{array}{l}\text { Type of cancer } \\
\text { (ICD-10) }\end{array}$} & \multicolumn{2}{|c|}{ Brazil } & \multicolumn{2}{|c|}{ São Paulo } & \multicolumn{2}{|c|}{ Porto Alegre } & \multicolumn{2}{|c|}{ João Pessoa } & \multicolumn{2}{|c|}{ Goiânia } & \multicolumn{2}{|c|}{ Fortaleza } & \multicolumn{2}{|c|}{ Cuiabá } & \multicolumn{2}{|c|}{ Belo Horizonte } & \multicolumn{2}{|c|}{ Aracaju } \\
\hline & $\mathrm{n}$ & Rate & $\mathrm{n}$ & Rate & $\mathrm{n}$ & Rate & $\mathrm{n}$ & Rate & $\mathrm{n}$ & Rate & $\mathrm{n}$ & Rate & $\mathrm{n}$ & Rate & $\mathrm{n}$ & Rate & $\mathrm{n}$ & Rate \\
\hline Total & 1,296 & 5.3 & 95 & 6.0 & 17 & 8.9 & 3 & 3.0 & 13 & 6.7 & 25 & 7.1 & 8 & 9.7 & 15 & 4.1 & 8 & 9.7 \\
\hline Brain (C71) & 173 & 0.7 * & 12 & 0.8 & 5 & 2.6 * & 1 & 1.0 * & 2 & 1.0 * & 8 & 2.3 & 0 & 0.0 & 3 & 0.8 * & 2 & 2.4 * \\
\hline Myeloid leukemia (C92) & 142 & 0.6 & 15 & 0.9 * & 2 & 1.0 & 0 & 0.0 & 1 & 0.5 & 1 & 0.3 & 1 & 1.2 * & 1 & 0.3 & 1 & 1.2 \\
\hline $\begin{array}{l}\text { Non-Hodgkin lymphoma } \\
(\mathrm{C} 82, \mathrm{C} 83, \mathrm{C} 85)\end{array}$ & 78 & 0.3 & 0.5 & 0.5 & 2 & 1.0 & 0 & 0.0 & 0 & 0.0 & 2 & 0.6 & 0 & 0.0 & 1 & 0.3 & 0 & 0.0 \\
\hline $\begin{array}{l}\text { Bones and articular cartilage } \\
(\mathrm{C} 40, \mathrm{C} 41)\end{array}$ & 74 & 0.3 & 0.3 & 0.3 & 1 & 0.5 & 1 & 1.0 * & 0 & 0.0 & 0 & 0.0 & 0 & 0.0 & 1 & 0.3 & 0 & 0.0 \\
\hline Lymphocytic leukemia (C91) & 64 & 0.3 & 8 & 0.5 & 0 & 0.0 & 0 & 0.0 & 1 & 0.5 & 1 & 0.3 & 0 & 0.0 & 2 & 0.6 & 2 & $2.4^{*}$ \\
\hline Uterine cervix (C53) & 61 & 0.2 & 2 & 0.1 & 0 & 0.0 & 0 & 0.0 & 0 & 0.0 & 1 & 0.3 & 0 & 0.0 & 0 & 0.0 & 0 & 0.0 \\
\hline Ovary (C56) & 60 & 0.2 & 2 & 0.1 & 0 & 0.0 & 0 & 0.0 & 1 & 0.5 & 1 & 0.3 & 0 & 0.0 & 1 & 0.3 & 1 & 1.2 \\
\hline Stomach (C16) & 50 & 0.2 & 2 & 0.1 & 1 & 0.5 & 0 & 0.0 & 0 & 0.0 & 1 & 0.3 & 1 & 1.2 * & 1 & 0.3 & 0 & 0.0 \\
\hline Hodgkin disease (C81) & 50 & 0.2 & 3 & 0.2 & 1 & 0.5 & 0 & 0.0 & 1 & 0.5 & 0 & 0.0 & 1 & 1.2 * & 0 & 0.0 & 0 & 0.0 \\
\hline $\begin{array}{l}\text { Leukemia, cell type } \\
\text { unspecified (C95) }\end{array}$ & 45 & 0.2 & 0 & 0 & 0 & 0.0 & 0 & 0.0 & 0 & 0.0 & 1 & 0.3 & 0 & 0.0 & 1 & 0.3 & 0 & 0.0 \\
\hline $\begin{array}{l}\text { Connective tissue and other } \\
\text { soft tissues (C49) }\end{array}$ & 33 & 0.1 & 2 & 0.1 & 0 & 0.0 & 0 & 0.0 & 2 & 1.0 & 2 & 0.6 & 1 & 1.2 * & 0 & 0.0 & 0 & 0.0 \\
\hline Bronchi and lungs (C34) & 32 & 0.1 & 2 & 0.1 & 0 & 0.0 & 0 & 0.0 & 0 & 0.0 & 3 & 0.9 & 1 & 1.2 * & 0 & 0.0 & 0 & 0.0 \\
\hline Breast (C50) & 30 & 0.1 & 3 & 0.2 & 0 & 0.0 & 0 & 0.0 & 1 & 0.5 & 0 & 0.0 & 1 & 1.2 * & 1 & 0.3 & 0 & 0.0 \\
\hline Melanoma (C43) & 22 & 0.1 & 0 & 0.0 & 3 & 1.6 & 0 & 0.0 & 0 & 0.0 & 0 & 0.0 & 0 & 0.0 & 1 & 0.3 & 0 & 0.0 \\
\hline
\end{tabular}

ICD-10: International Classification of Diseases, 10th Revision.

* Highest mortality rate in Brazil or in the city during this period.

cancer in females $(0.7$ deaths $/ 100,000)$. Mortality rates from cancer in other tumor sites, in decreasing order, were: myeloid leukemia $(0.6 / 100,000)$, non-Hodgkin lymphoma $(0.3 / 100,000)$, cancer of the bones and articular cartilage $(0.3 / 100,000)$, and lymphocytic leukemia $(0.3 / 100,000)$.

Brain cancer showed the highest mortality rate in Porto Alegre (2.6/100,000), followed by Aracaju $(2.4 / 100,000)$ and Fortaleza $(2.3 / 100,000)$. The highest mortality rates from myeloid leukemia were in Cuiabá and Aracaju (1.2/100,000), followed by Porto Alegre $(1.0 / 100,000)$ and São Paulo $(0.9 / 100,000)$

Non-Hodgkin lymphoma showed the highest mortality rate in Porto Alegre (1.0/100,000), tumors of the bones and articular cartilage in João Pessoa (1.0/100,000), and lymphocytic leukemia in Aracaju (2.4/100,000).

Table 5 shows the analysis of trends in mortality rates for men and women 20 to 24 years of age in Brazil for the periods 1980-2008 and 19992008.

In young men, there was a slight increase in the mortality rate from all forms of cancer in 1999-2008 (AAPC: 0.9; 95\%CI: 0.4; 1.4), while in young women the mortality rates from all cancers remained stable. The same period also witnessed an increase in mortality rates from brain cancer in young men (AAPC: 6.9 ; 95\%CI: 3.0; 11.0), and a stable rate trend in women.

As for mortality rates from lymphocytic leukemia, there was an increase during both periods in both genders, slightly higher in women (AAPC: 1.5 ; 95\%CI: $0.2 ; 2.8$ ) as compared to men (AAPC: 1.3 ; $95 \% \mathrm{CI}: 0.3 ; 2.2$ ). The mortality rates from cancer of the bones and articular cartilage and from myeloid leukemia remained stable in both young men and women during both periods.

\section{Discussion}

To our knowledge, this study was the first attempt at an analysis of the epidemiological distribution (incidence, hospital morbidity, and mortality) of cancer in young adults (20-24 years of age) in Brazil. Characterization of incidence rates was based on data from eight population-based cancer registries from Brazilian State capitals, selected according to internationally recommended data quality criteria. This strategy was used due to the absence of nationwide data and to allow 
Average annual percent change (AAPC) in cancer mortality rate by gender, 20-24 years, Brazil, 1980-2008.

\begin{tabular}{|c|c|c|c|c|}
\hline \multirow[t]{3}{*}{ Type of cancer (ICD-10) } & \multicolumn{2}{|c|}{ Men } & \multicolumn{2}{|c|}{ Women } \\
\hline & $1980-2008$ & 1999-2008 & 1980-2008 & $1999-2008$ \\
\hline & AAPC $(95 \% \mathrm{Cl})$ & AAPC $(95 \% \mathrm{Cl})$ & AAPC $(95 \% \mathrm{Cl})$ & AAPC $(95 \% \mathrm{Cl})$ \\
\hline All sites & $0.1(-0.4 ; 0.7)$ & $0.9 *(0.4 ; 1.4)$ & $-0.2(-0.9 ; 0.5)$ & $-0.3(-1.9 ; 1.4)$ \\
\hline Brain (C71) & $2.5(-0.6 ; 5.7)$ & $6.9 *(3.0 ; 11.0)$ & $-0.2(-4.6 ; 4.5)$ & $-0.9(-6.2 ; 4.8)$ \\
\hline Bones and articular cartilage (C40. C41) & $0.7(-0.2 ; 1.5)$ & $0.7(-0.2 ; 1.5)$ & $1.1(-0.1 ; 2.4)$ & $1.1(-0.1 ; 2.4)$ \\
\hline Lymphocytic leukemia (C91) & $1.3 *(0.3 ; 2.2)$ & $1.3 *(0.3 ; 2.2)$ & $1.5 *(0.2 ; 2.8)$ & $1.5 *(0.2 ; 2.8)$ \\
\hline Myeloid leukemia (C92) & $0.2(-0.4 ; 0.9)$ & $0.2(-0.4 ; 0.9)$ & $0.2(-0.5 ; 1.0)$ & $0.2(-0.5 ; 1.0)$ \\
\hline
\end{tabular}

ICD-10: International Classification of Diseases, 10th Revision; $95 \% \mathrm{Cl}$ : 95\% confidence interval.

* AAPC significantly different from zero.

the characterization of regional patterns in the distribution of cancer incidence rates in the selected age stratum. Morbidity and mortality rates used data available in the DATASUS for the entire country, as well as broken down for the selected State capitals according to incidence, thus allowing comparisons between these indicators (incidence, hospital morbidity, and mortality). In addition, the trends in the rates were only analyzed with national data, due to the limited number of years in which the population-based cancer registries have been in operation and the large number of years with no deaths reported in the selected cities, making it impossible to conduct statistical analyses for the incidence and mortality data.

Testicular cancer was the principal anatomical site among Brazilian men 20 to 24 years of age. Among women in the same age stratum, neoplasms of the thyroid and uterine cervix and Hodgkin disease were the most frequent.

The study revealed distinct regional distribution patterns in the incidence rates for testicular and cervical cancer. While testicular cancer showed high rates in the State capitals in the South of Brazil, intermediate rates in the Southeast, and lower rates in the Central-West and Northeast, the distribution was the opposite for cervical cancer, with the highest rates both in a State capital from the Northeast and from the Southeast.

A comparison of incidence rates for these tumors in populations of the same age stratum in other countries shows that for testicular cancer, Porto Alegre $(10.9 / 100,000)$ presented an incidence rate similar to the highest reported international rates, as in the Southern Netherlands (9.7/100,000 in 1993-1999) 9 and in white males in the United States (9.4/100,000 in 1995-1999) 10.
São Paulo showed an intermediate incidence rate $(4.3 / 100,000$ in $1999-2004)$, similar to the North of England (4.5/100,000 in 1968-1997) 11 , while the other selected Brazilian cities displayed low incidence rates, relatively similar to black males in the United States (1.3/100,000 in 1995-1999) 10.

Lacerda et al. 12 analyzed trends in the incidence rates of testicular cancer in two periods (1967-1976 and 1987-1996) in men 20-24 years of age in eight cities in Canada, Israel, Japan, Denmark, Finland, Norway, Sweden, and England and found an increase in incidence rates in all the selected populations. The populations in Finland, Israel, Norway, Sweden, and Canada showed an increase of more than $100 \%$ between the two periods, while those of Japan, Denmark, and England increased by around 50\%, suggesting that exposure to environmental factors in recent decades may be associated with the change in the distribution pattern of the disease.

As for cancer of the uterine cervix, the incidence rates in some Brazilian State capitals such as Aracaju, São Paulo, and Porto Alegre were higher than in developed countries. The other selected Brazilian cities showed intermediate rates, similar to international rates. Thus, while the United States had a rate of 2.6/100,000 in 1992-1997 13 and the North of England had 2.1/100,000 in 1968-1997 11, similar to Cuiabá $(2.4 / 100,000)$ and Goiânia $(2.1 / 100,000)$, the rates were higher in Aracaju (6.1/100,000) and São Paulo $(4.8 / 100,000)$

In summary, testicular cancer rates in developed countries tend to be similar to those in the State capitals in the South and Southeast of Brazil, while incidence rates for cervical cancer in the developed countries tend to be lower than those observed in Brazil. However, these data should 
be analyzed with caution due to the differences between periods analyzed in each country.

Observational studies estimate that early detection of precursor lesions of cervical cancer by Pap smear screening combined with effective treatment of detected lesions can reduce cervical cancer incidence by as much as $90 \%$ in the general population (while this reduction is somewhat smaller in younger women). However, such results are only achieved with high screening coverage (approximately 80\%) and testing conducted according to recommended quality guidelines 14 . According to information from the Pact for Health (DATASUS. Pacto pela Saúde, 2010/2011. http:// tabnet.datasus.gov.br/cgi/dh.exe?pacto/2010/ cnv/pactbr.def, accessed on 01/Jan/2011), during 2007-2010 this target was not reached in any of the eight cities selected for the current study. The best coverage for Pap smear screening among women in the 25-59 years of age in these cities was in João Pessoa in 2007-2009, but with coverage of only $23 \%$ of the target population. Coverage was even lower (only $3 \%$ of the target population in 2007) in Aracaju, the city with the highest cervical cancer incidence rate in the 20-24-year stratum $(6.1 / 100,000)$ among the selected cities, highlighting that greater investments and reorganization of public health care services could have an impact on this adverse reality.

As for thyroid cancer, much higher incidence rates were observed in the selected Brazilian cities than expected for this age stratum. A comparison of thyroid cancer incidence rates in the selected Brazilian cities with those in 20-24-year-old adults in other countries shows that while the rates in Brazilian men ranged from 0.7 to $2.8 / 100,000$, the rate was $1.0 / 100,000$ in the United States in 1992199713 and 0.3/100,000 in the North of England in 1968-1997 11. For women 20 to 24 years of age, the incidence rate in the United States in 1992-1997 $(5.7 / 100,000) 13$ was similar to the rates in Aracaju $(6.1 / 100,000)$ and São Paulo $(6.0 / 100,000)$, while the rate in the North of England was only 1.0/100,000 women in 1968-1997 11.

An indicator used to analyze cancer distribution in the Brazilian national population and in the selected cities was the proportion of hospital admissions due to cancer in the Brazilian Unified National Health System (SUS). Unlike mortality, which is a single event, hospitalization can occur several times in the same patient, or only once in others. In addition, although cancer is a serious disease requiring medical attention, a certain proportion of patients may not have been diagnosed as such (e.g., leukemia) or may not have had access to oncologic care, with both situations leading to underreporting of cases. Although these limitations mean that the hospital admis- sions rate for cancer differs from the incidence rate, the proportion of hospital admissions for a given disease in relation to total hospitalizations in a given age stratum allows comparison of the distribution of diseases between different populations.

This analysis revealed that the percentage of admissions for cancer in 2000-2002 was relatively similar in men and women, both in Brazil as a whole and in the selected cities. However, the data refer only to hospital admissions in the SUS (public hospitals or private hospitals outsourced by the public system), meaning that any attempt at inference on the population's cancer profile should be made with caution.

Although brain cancer did not show extremely high incidence rates in men and women 20 to 24 years of age, it was the leading cause of death from cancer in this age bracket in both sexes. This same pattern has been described elsewhere in the world. Although brain cancer is not very frequent, it contributes significantly to mortality, since it generally entails a poor prognosis. The most common histopathological type of primary brain tumor, glioblastoma, is considered surgically incurable and displays marked resistance to radiotherapy and chemotherapy, leading to a three-year survival of only $3 \% 15$. However, the mortality rates from brain cancer in young adults (20-24 years) in Brazil are slightly higher than in the same age stratum in the United States, especially in women. While the brain cancer mortality rate in Brazil was $0.8 / 100,000$ in men and 0.7/100,000 in women in 2000-2002, mortality rates from cancer of the brain and nervous system in the United States in 20002004 were $0.67 / 100,000$ in men and 0.46/100,000 in women (National Cancer Institute. Cancer mortality maps. http://ratecalc.cancer.gov/, accessed on $01 /$ Feb/2012).

Unfortunately, the literature on the distribution of cancer incidence and mortality in the 2024-year age stratum is still extremely limited, not only in Brazil, but elsewhere in the world, thus hindering comparisons of Brazil's epidemiological indicators with those of other countries.

Analysis of trends in mortality rates in young adults (20-24 years) in Brazil showed a slight increase in all cancer sites and a marked rise in brain cancer, both in males and in the period from 1999 to 2008. There was also an increase in lymphocytic leukemia in both sexes from 1980 to 2008 and from 1999 to 2008. Meanwhile, mortality rates from bone and joint cancer and myeloid leukemia remained stable in both sexes during the two target periods. The data suggest that the observed increases in brain cancer and lymphocytic leukemia may actually represent real increases and not merely the result of improved 
reporting of mortality data in the country. Importantly, this rise in mortality from lymphocytic leukemia contrasts with the downward trend in mortality rates from leukemia as a whole in individuals under 15 years of age in Brazil 16 .

Several studies have analyzed the under use of mortality data in Brazil, due not only to the data's limitations but also to the unjustified belief that such limitations would definitively compromise any result potentially derived from them 17 . The limitations of mortality data are related to coverage and the reliability of data completion in death certificates, especially in the poorer regions of the country. However, studies in Brazil have evaluated the reliability and validity of death certificates for cancer patients by comparing the reported and true causes of death, indicating the presence of high reliability 18,19 .

Another limitation to our study relates to cancer incidence data. The lack of implementation of standardized data collection protocols has led to heterogeneity in data coverage and quality. Additionally, the periods with available data differ between the population-based cancer registries, and in some cases such periods are very short. To minimize the limitation caused by the quality of incidence data, the cancer registries used in this study were selected on the basis of internationally accepted data quality criteria ${ }^{8}$.

As a whole, the results presented here portray an epidemiological pattern of cancer in young adults in Brazil with some specific characteristics of regional distribution. The latter reveal a pattern with some similarities in incidence (as in testicular cancer) and heterogeneity (cervical cancer and thyroid cancer) in relation to those reported in developed countries. Importantly, the study indicates the lack of a decline in mortality from various cancers in young adults in Brazil in last three decades and an increase in mortality from brain cancer and especially lymphocytic leukemia. This highlights the need to conduct survival studies on cancer in young Brazilian adults, as well as studies with tumor samples, exploring the biological characteristics of these neoplasms and studies on the special needs of the population group that develops this disease.

\section{Resumen}

En el mundo todavía son relativamente pocos los estudios sobre la incidencia y mortalidad por cáncer en adultos jóvenes. El objetivo fue explorar la distribución de cáncer en adultos jóvenes en Brasil. Se realizó un estudio descriptivo de la incidencia (capitales seleccionadas), de la morbilidad hospitalaria y de la mortalidad (Brasil y capitales seleccionadas) por cáncer a los 20-24 años, en el período de 2000-2002, y de la evolución de las tasas de mortalidad por cáncer en Brasil en el período de 1980-2008, en la misma población. El cáncer de testículo fue la principal localización anatómica en hombres, y las neoplasias de la glándula tiroides, del cuello de útero y la enfermedad de Hodgkin en las mujeres. El cáncer de encéfalo fue la principal causa de muerte por cáncer en ambos sexos y la tendencia temporal de la mortalidad muestra un aumento en la mortalidad por cáncer de encéfalo en hombres y por la leucemia linfoide en ambos sexos. En conjunto, los resultados presentados retratan un padrón epidemiológico de cáncer en adultos jóvenes en Brasil con características regionales de distribución.

Neoplasias; Adulto Joven; Morbilidad; Mortalidad 


\section{Contributors}

S. S. Santos participated in the data analysis and interpretation, writing of the article, and approval of the final version for publication. L. R. Melo collaborated in the data analysis and interpretation, relevant critical revision of the intellectual content, and approval of the final version for publication. R. J. Koifman and S. Koifman contributed to the study conceptualization and project, relevant critical revision of the intellectual content, and approval of the final version for publication.

\section{Acknowledgments}

The authors wish to thank CAPES and CNPq for their financial support.

\section{References}

1. Bleyer A, Barr R, Hayes-Lattin B, Thomas D, Ellis C, Anderson B, et al. The distinctive biology of cancer in adolescents and young adults. Nat Rev Cancer 2008; 8:288-98.

2. Croucher C, Whelan JS, Møller H, Davies EA. Trends in the incidence and survival of cancer in teenagers and young adults: regional analysis for South East England 1960-2002. Clin Oncol (R Coll Radiol) 2009; 21:417-24.

3. Bleyer A. Young adult oncology: the patients and their survival challenges. CA Cancer J Clin 2007; 57:242-55.

4. Schmidt C. Lack of progress in teen and young adult cancers concerns researchers, prompts study. J Natl Cancer Inst 2006; 98:1760-3.

5. Smith S, Davies S, Wright D, Chapman C, Whiteson M. The experiences of teenagers and young adults with cancer: results of 2004 conference survey. Eur J Oncol Nurs 2007; 11:362-8.
6. Trevino KM, Maciejewski PK, Fasciano K, Greer JA, Partridge A, Kacel EL, et al. Coping and psychological distress in young adults with advanced cancer. J Support Oncol 2012; 10:124-30.

7. D'Orazio JA. Inherited cancer syndromes in children and young adults. J Pediatr Hematol Oncol 2010; 32:195-228.

8. Coordenação de Prevenção e Vigilância, Instituto Nacional de Câncer. Câncer no Brasil: dados dos registros de base populacional. v. 4. Rio de Janeiro: Instituto Nacional de Câncer; 2010.

9. Reedijk AM, Janssen-Heijnen ML, Louwman MW, Snepvangers Y, Hofhuis WJ, Coebergh JW. Increasing incidence and improved survival of cancer in children and young adults in Southern Netherlands, 1973-1999. Eur J Cancer 2005; 41:760-9.

10. Wu X, Groves FD, McLaughlin CC, Jemal A, Martin J, Chen VW. Cancer incidence patterns among adolescents and young adults in the United States. Cancer Causes Control 2005; 16:309-20. 
11. Pearce MS, Parker L, Windebank KP, Cotterill SJ, Craft AW. Cancer in adolescents and young adults aged 15-24 years: a report from the North of England young person's malignant disease registry, UK. Pediatr Blood Cancer 2005; 45:687-93.

12. Lacerda HM, Akre O, Merletti F, Richiardi L. Time trends in the incidence of testicular cancer in childhood and young adulthood. Cancer Epidemiol Biomarkers Prev 2009; 18:2042-5.

13. Wu XC, Chen VW, Steele B, Roffers S, Klotz JB, Correa $\mathrm{CN}$, et al. Cancer incidence in adolescents and young adults in the United States, 1992-1997. J Adolesc Health 2003; 32:405-15.

14. Gustafsson L, Pontén J, Zack M, Adami HO. International incidence rates of invasive cervical cancer after introduction of cytological screening. Cancer Causes Control 1997; 8:755-63.

15. Boyle P, Levin B, editors. World cancer report 2008. Lyon: IARC Press; 2008.
16. Couto AC, Ferreira JD, Koifman RJ, Monteiro GT, Pombo-de-Oliveira MS, Koifman S. Trends in childhood leukemia mortality over a 25 -year period. J Pediatr (Rio J.) 2010; 86:405-10.

17. Paes NA. Qualidade das estatísticas de óbitos por causas desconhecidas dos Estados brasileiros. Rev Saúde Pública 2007; 41:436-45.

18. Monteiro GTR, Koifman RJ, Koifman S. Confiabilidade e validade dos atestados de óbito por neoplasias. I. Confiabilidade da codificação para o conjunto das neoplasias no Estado do Rio de Janeiro. Cad Saúde Pública 1997; 13 Suppl 1:39-52.

19. Fajardo S, Aerts DRGC, Bassanesi SL. Acurácia da equipe do Sistema de Informações sobre Mortalidade na seleção da causa básica do óbito em capital no Sul do Brasil. Cad Saúde Pública 2009; 25:2218-28.

Submitted on 18/Aug/2011

Final version resubmitted on $04 / \mathrm{Jul} / 2012$

Approved on 06/Dec/2012 
Santos SS, Melo LR, Koifman RJ, Koifman S. Cancer incidence, hospital morbidity, and mortality in young adults in Brazil. Cad Saúde Pública 2013; 29(5):1029-1040.

A revista foi informada sobre um erro no títulos das Tabelas 3 e 4 do artigo. Os títulos corretos são: The journal has been informed of an error in the titles of Tables 3 and 4 . The correct titles are:

La revista fue informada sobre un error en los títulos de las Tablas 3 y 4 . Los títulos correctos son:

Table 3

Cancer mortality in main anatomical sites in selected cities, males, 20-24 years. Brazil, 2000-2002.

Table 4

Cancer mortality in main anatomical sites in selected cities, females, 20-24 years. Brazil, 2000-2002.

Obs.: A versão eletrônica, disponível em HTML e PDF através da Scientific Electronic Library Online (SciELO; http://www.scielo.br/csp), está correta.

Note: The electronic version is correct and is available in HTML and PDF through the Scientific Electronic Library Online (SciELO; http://www. scielo.br/csp).

Nota: La versión electrónica, disponible en HTML y PDF a través de la Scientific Electronic Library Online (SciELO; http://www.scielo.br/csp), está correcta. 